\title{
Effect of Perilla frutescens Extract on Nitric Oxide Production by Cultured Murine Mesangial Cells
}

\author{
Toshiaki Makino, ${ }^{a}$ Takahiko Ono, ${ }^{b}$ Michiho Ito, ${ }^{a}$ Eri Muso, ${ }^{b}$ and Gisho HondA ${ }^{*, a}$ \\ Graduate School of Pharmaceutical Sciences, ${ }^{a}$ Kyoto University, Kyoto 606-8501, Japan and Graduate School of \\ Medicine, ${ }^{b}$ Kyoto University, Kyoto 606-8507, Japan. Received October 22, 1998; accepted February 22, 1999
}

\begin{abstract}
The effects of a water extract of perilla (Perilla frutescens BRITTON) leaves on nitric oxide (NO) production by cultured murine mesangial cells were investigated. Perilla extract significantly induced NO production from mesangial cells, which was enormously augmented without cytotoxity by combination with interferon (IFN)- $\gamma$ or tumor necrosis factor- $\alpha$. On the other hand, perilla extract suppressed a large amount of NO production induced by IFN- $\gamma$ combined with lipopolysaccharide. Northern blot analysis revealed that such effects of perilla extract were dependent on inducible NO synthase mRNA expression. Perilla extract exhibited an inhibitory effect on cytokine-induced mesangial cell proliferation, and this effect was significantly decreased upon combination with $\mathrm{N}^{\mathrm{G}}$-monomethyl-L-arginine (L-NMMA), a non-specific NO synthase inhibitor, suggesting that perilla extract inhibits mesangial cell proliferation partially through the induction of NO production. Such results indicate that perilla may be a promising agent for the prevention of the progression of glomerulonephritis.
\end{abstract}

Key words Perilla frutescens; Labiatae; mesangial cell; nitric oxide; proliferation; glomerulonephritis

Perilla frutescens BRITTON var. crispa (perilla, Labiatae) is one of the most common herbs in Japan. Perilla leaves frequently accompany seafood, as the leaves are believed to prevent food poisoning and to protect the digestive tract from inflammatory diseases. Several studies on the pharmacological activities of the herb in relation to sedation, ${ }^{1)}$ indigestion, ${ }^{2)}$ and food poisoning ${ }^{3)}$ have been reported. Traditional usage of the herb led to the expectation that the leaves possess an inhibitory effect against food allergies. Indeed, several anti-allergic effects of the leaves have been reported. ${ }^{4-7)}$ In traditional Kampo medicine, the perilla leaves are one of the components of Saiboku-to, which is occasionally used to treat bronchial asthma. ${ }^{8}$ A previous study of the authors demonstrated the prominent inhibitory effects on cultured murine mesangial cell proliferation by Saiboku-to. ${ }^{9}$ Perilla leaves are considered to play a significant role in the prescription of Saiboku-to in achieving the anti-asthmatic ${ }^{5)}$ and anti-proliferative effect. ${ }^{10)}$

Recently, the role of nitric oxide (NO) on glomerulonephritis has been elucidated. ${ }^{11,12}$ The renal vascular bed produces large amounts of NO to maintain renal blood flow (RBF) and the glomerular filtration rate (GFR). In normal rats, the intravenous infusion of a NO synthase inhibitor reduced RBF and GFR at a dose that did not modify systemic blood pressure. ${ }^{13)}$ These facts suggested that NO plays important roles in the kidneys. NO protects kidneys as an endogenous mediator, antagonizing angiotensin II action, ${ }^{14,15)}$ suppressing platelet aggregation, ${ }^{16)}$ and inhibiting the proliferation ${ }^{17)}$ and matrix protein synthesis ${ }^{18,19)}$ of mesangial cells.

In the authors' previous study, it was demonstrated that perilla extract exerted an inhibitory effect on cytokine-induced mesangial cell proliferation and that phenolic compounds, such as caffeic acid or luteolin, are the anti-proliferative constituents. ${ }^{10)}$ Since Saiboku-to stimulates NO production in cultured canine epithelium, ${ }^{20)}$ it is assumed that perilla extract might inhibit mesangial cell proliferation via the induction of NO, which acts as an autocrine factor to suppress cell proliferation. In the present study, the effect of perilla extract on NO production in cultured murine mesangial cells and its influence on anti-proliferative effect were investi- gated.

\section{MATERIALS AND METHODS}

Preparation of Perilla Extract Perilla frutescens BRITTON var. crispa (strain No. 32) was cultivated in the Experimental Station for Medical Plant Research, Faculty of Pharmaceutical Sciences, Kyoto University; the leaves were harvested in August, 1996. Strain No. 32 was examined in this study with purple leaves and the smell of perillaldehyde; it has been recommended in Kampo medicine. Fresh leaves $(137.7 \mathrm{~g})$ were extracted by agitation with 1.41 of distilled water at room temperature for $24 \mathrm{~h}$. The extract was concentrated under reduced pressure to yield a dried extract $(6.5 \mathrm{~g}$, extraction ratio $: 4.7 \%$ ).

Materials Human recombinant platelet derived growth factor-BB (PDGF), human recombinant tumor necrosis factor (TNF)- $\alpha$, and murine recombinant interferon (IFN)- $\gamma$, were purchased from Gibco BRL (Gaithersburg, MD, U.S.A.), Genzyme (Cambridge, MA, U.S.A.), and Pharmingen (San Diego, CA, U.S.A.), respectively. Lipopolysaccharide (LPS) from E. coli. serotype 026:B6 was purchased from Sigma (St. Louis, MO, U.S.A.). Sulfanilamide and 3(4,5-dimethylthiazol-2-yl)-2,5-diphenyl tetrazolium bromide (MTT) were purchased from Nacalai Tesque (Kyoto, Japan). Finally, $\mathrm{N}^{\mathrm{G}}$-monomethyl-L-arginine (L-NMMA) and naphthylethylenediamine dihydrochloride were bought from Research Biochemical International (Napick, MA, U.S.A.), and Wako Pure Chemical Industries (Osaka, Japan), respectively.

Mesangial Cell Culture Murine mesangial cells were prepared by the method of MacKay et al. ${ }^{21)}$ Glomeruli were isolated from Balb/c mice (Shimizu Laboratory Materials, Kyoto, Japan) by sieving. A culture was prepared in a $3: 1$ mixture of Dulbecco's modified eagle medium and F12 nutrient (Gibco BRL) supplemented with $20 \%$ fetal calf serum (FCS, Biowhittaker, Walkersville, MD, U.S.A.), $100 \mathrm{U} / \mathrm{ml}$ penicillin $\mathrm{G}$ and $100 \mu \mathrm{g} / \mathrm{ml}$ streptomycin (Gibco BRL) in $5 \%$ $\mathrm{CO}_{2}$ at $37^{\circ} \mathrm{C}$. Mesangial cells surrounding the glomeruli were removed using cloning rings and were cultured under the above conditions. Cells between the 5 th and 15 th passage 
were used for the experiments.

Measurement of Nitrite The production of NO by cultured mesangial cells was determined by measurement of the concentration of nitrite, a stable NO oxidation product, in the cultured medium. Mesangial cells grown in 96-well plates $\left(3 \times 10^{4}\right.$ cells/well $)$ were treated with $10 \%$ FCS medium containing both various concentrations of perilla extract and cytokines. The medium was subsequently collected and the nitrite concentration was measured by mixing the medium with an equal volume of Griess reagent ( 1 part of $0.1 \%$ naphthylethylenediamine dihydrochloride to 1 part of $1 \%$ sulfanilamide in $5 \%$ phosphoric acid). ${ }^{22)}$ The optical density at 540 $\mathrm{nm}$ was measured, and the nitrite concentration was determined from a standard curve calibrated with $\mathrm{NaNO}_{2}$ solution.

Measurement of DNA Synthesis DNA synthesis was measured in the manner of the authors' previous study. ${ }^{10)}$ After seeding mesangial cells into 24 -well plates $\left(2 \times 10^{4}\right.$ cells/well) and incubating them for $48 \mathrm{~h}$, the culture medium was replaced with a FCS-free medium. Quiescent cells were stimulated with a medium containing PDGF $(10 \mathrm{ng} / \mathrm{ml})$ or TNF- $\alpha(100 \mathrm{U} / \mathrm{ml}$ in $0.5 \%$ FCS-medium $)$ combined with perilla extract and L-NMMA $(0.5 \mathrm{~mm})$ for $24 \mathrm{~h} .1 \mu \mathrm{Ci} /$ well of $\left[{ }^{3} \mathrm{H}\right]$ thymidine $(6.7 \mathrm{Ci} / \mathrm{mmol}$, Amersham Life Sciences, Buckinghamshire, UK) was added to the medium for the last $4 \mathrm{~h}$. After the cells were lysed and precipitated with $5 \%$ trichloroacetic acid, the radioactivity was measured by a liquid scintillation counter (Aloka, Tokyo, Japan).

RNA Purification and Northern Blot Analysis Mesangial cells were grown in $10 \mathrm{~cm}$ dishes until they reached subconfluency, then subsequently cultured with the medium containing perilla extract and cytokines for $24 \mathrm{~h}$. Total RNA was extracted by the acid guanidinium-phenol-chloroform method. $^{23)}$ After separation of $20 \mu \mathrm{g}$ of RNA by $0.66 \mathrm{M}$ formaldehyde- $1.0 \%$ agarose gel electrophoresis, the RNA was transferred onto a nylon membrane (Biodyne, PALL, Glen Cove, NY, U.S.A.). A ${ }^{32}$ P labeled cDNA probe was prepared with Megaprime DNA labeling systems (Amersham). cDNA of inducible NO synthase (iNOS) and glyceraldehyde3-phosphate dehydrogenase (GAPDH) was provided by $\mathrm{Ox}-$ ford Biochemical Research, Inc. (Oxford, MI, U.S.A.) and American Type Culture Collection (Rockville, MD, U.S.A.), respectively. Hybridization was performed at $42^{\circ} \mathrm{C}$ for $12 \mathrm{~h}$; the membranes were washed four times over with $0.5 \%$ SDS in $1 \times \mathrm{SSC}$ at $42^{\circ} \mathrm{C}$ for $15 \mathrm{~min}$, then autoradiographed. The radioactivity of the corresponding bands was quantitatively measured by a Fuji BAS 2000 Bio-Image Analyzer (Fuji Film Co., Ltd., Tokyo, Japan). After stripping the radioactive iNOS probes off the membranes, rehybridization with GAPDH probes was performed. For quantitative densitometric measurements of Northern blots, iNOS signals were normalized to the signals for GAPDH. The experiment was repeated twice and the same results were yielded.

Evaluation of Cell Viability The cytotoxicities of perilla extract were evaluated via both the reducing activity of MTT and the amount of lactic dehydrogenase (LDH) released. For the MTT test, mesangial cells grown in 96-well plates $\left(1 \times 10^{4}\right.$ cells/well $)$ were incubated in the medium containing perilla extract for $48 \mathrm{~h}$. The medium was subsequently discarded and the cells were incubated for an additional $24 \mathrm{~h}$ in $10 \%$ FCS medium. This medium was then ex-

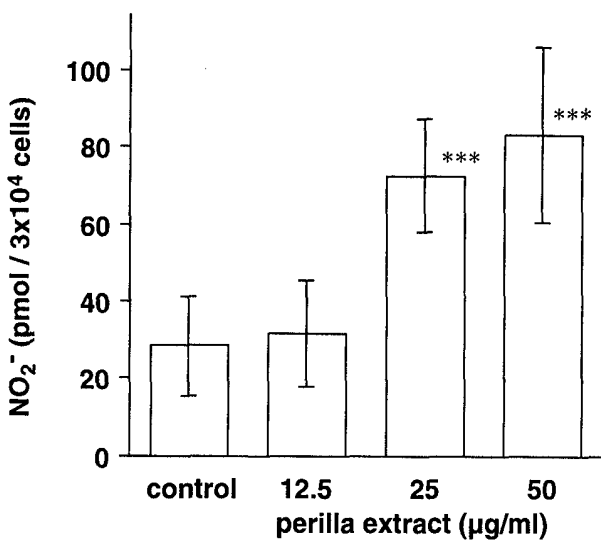

Fig. 1. Effect of Perilla Extract on Nitrite Release of Cultured Murine Mesangial Cells

Mesangial cells were treated with various concentrations of perilla extract for $48 \mathrm{~h}$ Data are represented as mean \pm S.D. $(n=6) . * * *$ indicates statistical significance $(p<0.001)$ compared to the control group.

changed for $100 \mu \mathrm{l}$ of a medium containing $0.5 \mathrm{mg} / \mathrm{ml} \mathrm{MTT}$ and incubated for $4 \mathrm{~h} .100 \mu \mathrm{l}$ of $0.04 \mathrm{~N} \mathrm{HCl}$ in isopropanol solution was subsequently added to each well to dissolve formazan crystals; the optical density at $570 \mathrm{~nm}$ was measured. ${ }^{24)}$ For the LDH release test, mesangial cells grown in 96-well plates $\left(3 \times 10^{4}\right.$ cells/well) were incubated for $48 \mathrm{~h}$ in a medium containing perilla extract. The medium was then collected and the cells were lysed with $1 \%$ Triton-X 100 . Determination of LDH activity was measured with an LDH assay reagent (Wako). The percentage of LDH release was calculated from the ratio of LDH activity in the medium to the sum of the LDH activity in the medium and in the cell lysate. $^{25)}$

Statistical Analysis Data were represented as mean \pm S.D. In statistical evaluation, Student's $t$-test was employed for cell viability, and one-way analysis of variance (ANOVA) followed by a multiple comparison procedure according to Fisher's protected least significant difference (PLSD) were employed for other multiple data. A difference of $p<0.05$ was considered to be significant.

\section{RESULTS}

Perilla extract significantly induced nitrite release from cultured mesangial cells in a dose-dependent manner (Fig. 1). In order to confirm whether the increased nitrite in the medium was dependent on the NO produced by mesangial cells, L-NMMA was used as a non-specific NO synthase (NOS) inhibitor. L-NMMA $(0.5 \mathrm{~mm})$ completely inhibited the effect of perilla extract on nitrite release (basal, 11.4 \pm 6.9 ; $25 \mu \mathrm{g} / \mathrm{ml}$ of perilla extract, $83.7 \pm 9.2 ; 25 \mu \mathrm{g} / \mathrm{ml}$ of perilla extract $+0.5 \mathrm{mM}$ of $\mathrm{L}-\mathrm{NMMA}, 22.2 \pm 13.3 \mathrm{pmol} / 3 \times 10^{4}$ cells $)$.

The synergism between perilla extract and well-known NO inducers such as IFN- $\gamma$, TNF- $\alpha$, and LPS was then evaluated. IFN- $\gamma(100 \mathrm{U} / \mathrm{ml})$ significantly induced nitrite release by mesangial cells, however, TNF- $\alpha(100 \mathrm{U} / \mathrm{ml})$ barely induced nitrite release. Perilla extract in combination with IFN$\gamma$ and TNF- $\alpha$ synergistically induced nitrite release in dosedependent manner (Figs. 2a, 2b). LPS (10 or $20 \mu \mathrm{g} / \mathrm{ml}$ ) significantly induced nitrite release from cultured mesangial cells. However such an effect was not augmented, but, rather significantly decreased by perilla extract $(25 \mu \mathrm{g} / \mathrm{ml})$ (Fig. 3a). 
a)

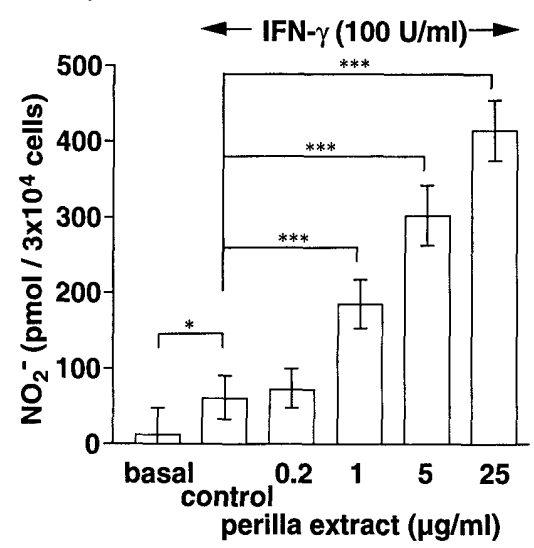

b)

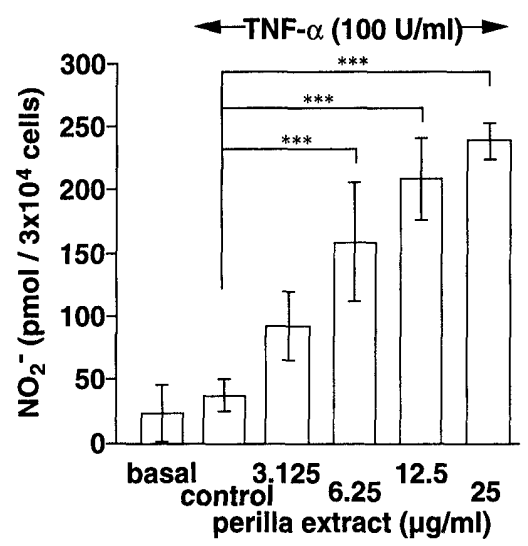

Fig. 2. Effect of Perilla Extract Combined with IFN- $\gamma$ (a) and TNF- $\alpha$ (b) on Nitrite Release of Cultured Murine Mesangial Cells Mesangial cells were treated in both cases for $48 \mathrm{~h}$. Data are represented as mean \pm S.D. $(n=6) . *$ and $* * *$ indicate statistical significance $(p<0.05$ and 0.001 , respectively).
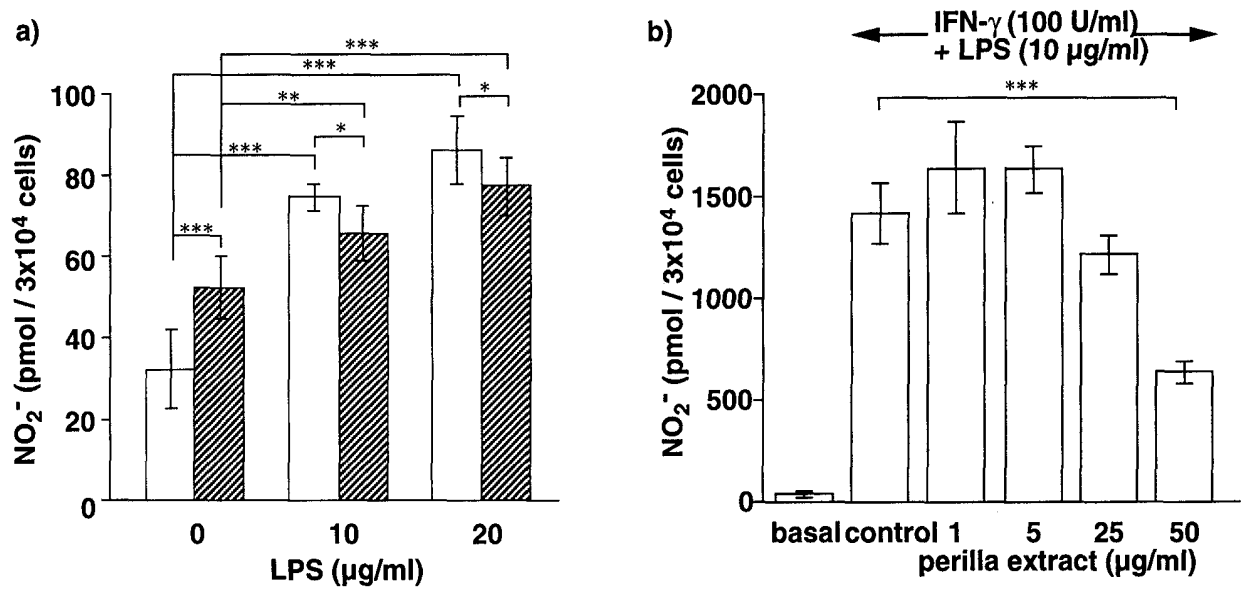

Fig. 3. Effect of Perilla Extract on Nitrite Release Induced by LPS (a) and LPS Combined with IFN- $\gamma$ (b) of Cultured Murine Mesangial Cells

(a) Open and hatched columns indicate the effects in normal medium and in medium containing $25 \mu \mathrm{g} / \mathrm{ml}$ perilla extract, respectively. (b) Mesangial celis were stimulated with $10 \mathrm{ng} / \mathrm{ml}$ LPS combined with $100 \mathrm{U} / \mathrm{ml} \mathrm{IFN}-\gamma$. Mesangial cells were treated for $48 \mathrm{~h}$. Data are represented as mean \pm S.D. $(n=6)$. *,**,***indicate statistical significance $(p<0.05$, 0.01 , and 0.001 , respectively).

To further investigate the inhibitory effect of perilla extract on LPS-induced nitrite release, mesangial cells were stimulated with LPS in combination with IFN- $\gamma$. LPS $(10 \mu \mathrm{g} / \mathrm{ml})$ coupled with IFN- $\gamma(100 \mathrm{U} / \mathrm{ml})$ induced a marked release of nitrite, yet was significantly inhibited by perilla extract in a dose-dependent manner (Fig. 3b).

In order to examine the mechanism of the nitrite release induced by perilla extract, a Northern blot analysis for NO synthase was performed. After incubating mesangial cells with the medium containing perilla extract and cytokines for $24 \mathrm{~h}, \mathrm{mRNA}$ was extracted. As shown in Fig. 4a, iNOS expression was slightly observed in the case of IFN- $\gamma(100$ $\mathrm{U} / \mathrm{ml}$ ) (lane 2) and in the case of the perilla extract $(25$ $\mu \mathrm{g} / \mathrm{ml}$ ) (lane 3), but was enormously augmented upon combination with perilla extract (lane 4) or LPS (lane 5). On the other hand, perilla extract $(50 \mu \mathrm{g} / \mathrm{ml})$ slightly suppressed the iNOS expression induced by IFN- $\gamma(100 \mathrm{U} / \mathrm{ml})$ combined with LPS $(10 \mu \mathrm{g} / \mathrm{ml})$ (Fig. 4b, lane 7 and 8 ).

The effect of perilla extract on cytokine-induced mesangial cell proliferation was examined. As shown in Fig. 5, perilla extract dose-dependently suppressed TNF- $\alpha$-induced mesangial cell proliferation. Such suppression was significantly diminished by the addition of L-NMMA $(0.5 \mathrm{mM})$, a non-specific NO synthase inhibitor, in a culture medium.
The viability of cultured mesangial cells was evaluated by the reducing activity of MTT and by the amount of LDH released. After $48 \mathrm{~h}$ of incubation, the number of formazan crystals reduced by mesangial cells and LDH released from the cells was not significantly affected by perilla extract and/or the cytokines (Table 1).

\section{DISCUSSION}

Perilla extract induced nitrite release in cultured murine mesangial cells. IFN- $\gamma$ and TNF- $\alpha$ are well-known inducers of NO production by mesangial cells and have also been observed to slightly stimulate nitrite release by mesangial cells. The release was extremely augmented upon coupling the cytokines with perilla extract. The nitrite release induced by perilla extract, or its combination with IFN- $\gamma$, was inhibited by L-NMMA, a non-specific NOS inhibitor in cultured mesangial cells. Northern blot analysis revealed that inducible effects of perilla extract on nitrite release was derived from the induction of iNOS mRNA. Kunz et al. reported that iNOS was triggered by two distinct signaling pathways in rat mesangial cells. ${ }^{26)}$ The murine iNOS gene was demonstrated to possess two different regulatory promoter regions: region I, the site for LPS-induced transcription factors; region II, the 
a) $\begin{array}{lllll}1 & 2 & 3 & 4 & 5\end{array}$

iNOS

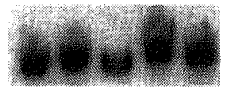

GAPDH<smiles>[10BH2-]</smiles>
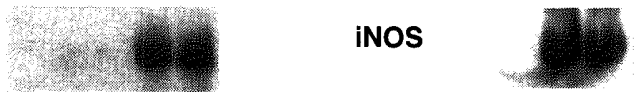

GAPDH

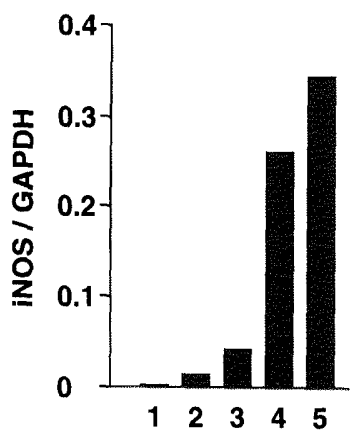

Fig. 4. Northern Blot Analysis for iNOS

After incubating mesangial cells with normal medium (lane 1), IF $-\gamma(100 \mathrm{U} / \mathrm{ml})$ alone (lane 2), perilla extract $(25 \mu \mathrm{g} / \mathrm{ml}$ ) alone (lane 3), IFN- $\gamma+$ perilla extract (lane 4), IFN- $\gamma+$ LPS $(10 \mu \mathrm{g} / \mathrm{ml}$ ) (lane 5), normal medium (lane 6), IFN- $\gamma+$ LPS (lane 7), and IFN- $\gamma+$ LPS + perilla extract $(50 \mu \mathrm{g} / \mathrm{ml})$ (lane 8$)$ for $24 \mathrm{~h}$. mRNA was extracted. The histograms demonstrate the ratio of iNOS radioactivity to GAPDH.

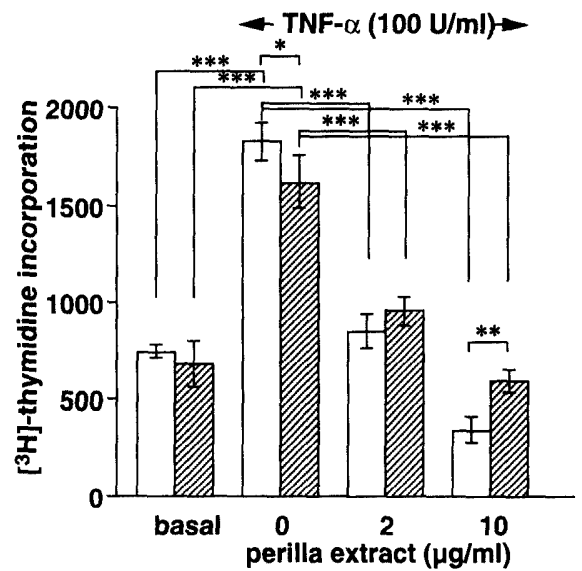

Fig. 5. Effect of Perilla Extract on Mesangial Cell Proliferation with or without L-NMMA Induced by TNF $\alpha$

Mesangial cells were treated with $100 \mathrm{U} / \mathrm{ml}$ TNF- $\alpha$ in the medium containing various concentrations of perilla extract and $0.5 \mathrm{~mm} \mathrm{L-NMMA}$ for $24 \mathrm{~h}$. Open and hatched columns indicate the effects in normal medium and the medium containing $0.5 \mathrm{mM} \mathrm{l}$.NMMA, respectively. Each column indicates the $\left[{ }^{3} \mathrm{H}\right]$ thymidine incorporation for the last $4 \mathrm{~h}$. Data are represented as mean \pm S.D. $(n=3), *, * * * * *$ indicate statistically significant $(p<0.05,0.01$, and 0.001 , respectively).

site for IFN- $\gamma$ or TNF- $\alpha$-induced transcription factors. ${ }^{11)}$ Consequently, LPS and IFN- $\gamma$ independently activated the iNOS gene to exert a synergistic effect of NO production. Perilla extract exhibited a synergistic effect of NO induction by either IFN- $\gamma$ or TNF- $\alpha$ which would activate region II, suggesting that perilla extract acts on the signal transduction of region I. However, perilla extract suppressed LPS-induced NO production, and such a suppressive effect was amplified when NO production was further stimulated by a combination of IFN- $\gamma$ with LPS. Although the detailed mechanism which would allow us to interpret such a biphasic effect of perilla extract remains unknown, it is expected that perilla
Table 1. Effect of Perilla Extract with or without Cytokines on Cell Viability

\begin{tabular}{lcc}
\hline & MTT test & LDH release test \\
\hline Control & $1.180 \pm 0.102$ & $33.1 \pm 9.0$ \\
Perilla extract $(50 \mu \mathrm{g} / \mathrm{ml})$ & $1.261 \pm 0.103$ & $25.6 \pm 1.0$ \\
Perilla extract $(25 \mu \mathrm{g} / \mathrm{ml})$ & & \\
+ IFN $\gamma(100 \mathrm{U} / \mathrm{ml})$ & $1.147 \pm 0.072$ & $25.9 \pm 2.4$ \\
+ TNF- $\alpha(100 \mathrm{U} / \mathrm{ml})$ & $1.049 \pm 0.084$ & $32.7 \pm 5.3$ \\
$\quad+$ LPS $(10 \mu \mathrm{g} / \mathrm{ml})$ & $1.184 \pm 0.089$ & $30.6 \pm 13.3$ \\
Perilla extract $(50 \mu \mathrm{g} / \mathrm{ml})$ & & \\
+ IFN- $\gamma(100 \mathrm{U} / \mathrm{ml})$ & $1.161 \pm 0.077$ & $26.0 \pm 1.3$ \\
& + LPS $(10 \mu \mathrm{g} / \mathrm{ml})$
\end{tabular}

No significant difference was observed compared to the control group. Data for MTT test are expressed as mean \pm S.D. $(n=5)$ of $\mathrm{OD}_{570}$. Data for LDH release test are expressed as mean \pm S.D. $(n=3)$ of the ratio of LDH released from the cells $(\%)$.

extract might inactivate LPS in the culture medium.

Several researchers reported that iNOS mRNA expression is augmented in kidneys suffering from acute glomerulonephritis. ${ }^{27-30)}$ iNOS is capable of producing more NO than endothelial NO synthase (eNOS). Such excessive NO production is generally considered to cause damage to the renal tissue, as NO is one of the reactive oxygen species. Furthermore, NO interacts with a superoxide anion to generate peroxynitrite, which is a potent cell membrane oxidant and may promote cell injury. Nonetheless, NO derived from iNOS does not always aggravate renal diseases. iNOS expression has been proposed to be a cytoprotector through the prevention of microthrombosis and reactive oxygen-mediated injury. ${ }^{31)}$ Gabbai et al. demonstrated that $\mathrm{L}^{-\mathrm{N}^{6}}$-(1-iminoethyl)lysine (L-NIL), a specific iNOS inhibitor, causes greater deteriorition of the rat anti-tubular basement membrane antibody-induced interstitial nephritis than $\mathrm{N}^{\mathrm{W}}$-nitro-L-arginine methyl ester (L-NAME), a non-specific NO synthase inhibitor. ${ }^{32)}$ Aiello et al. reported that renal insufficiency in a $5 / 6$ nephrectomized rat is a consequence of a progressive reduction in the amount of iNOS expressed in the kidney ${ }^{33)} \mathrm{Fu}$ rusu et al. reported that in human IgA nephropathy and lupus nephropathy, eNOS and iNOS were both observed in a reciprocal expression pattern in injured glomeruli, and that the induction of iNOS in mesangial cells would compensate for the reduced production of eNOS, thus protecting the kidneys. ${ }^{34)}$ Perilla extract solely induced NO production through iNOS expression in cultured mesangial cells. However, the inductive effect was reversed when NO production was highly promoted by IFN- $\gamma$ combined with LPS. On the other hand, perilla extract possesses anti-oxidative activity ${ }^{35)}$ and may prevent peroxynitrite production by scavenging superoxide anions. In this study, no cytotoxicity of perilla extract was observed in two independent experiments measuring the reducing activity of MTT and the amount of LDH released. Perilla extract may possess a biphasic effect: the induction of NO production to protect the kidneys; and the prevention of NOinduced toxicity.

$\mathrm{NO}$ is known to possess an anti-proliferative effect in terms of cultured mesangial cells ${ }^{17)}$; the same effect was also observed with perilla extract. ${ }^{(0)}$ Such results strongly suggest that the suppression of cultured mesangial cell proliferation by perilla extract is via an induction of NO, which acts as an autocrine factor. Perilla extract suppressed TNF- $\alpha$-induced mesangial cell proliferation, yet such suppression was signif- 
icantly diminished upon combination with L-NMMA. These results suggest that the perilla extract inhibits mesangial cell proliferation partially via NO production, and that other mechanisms such as an inhibitory effect on tyrosine kinase by some flavonoids ${ }^{36)}$ contained in perilla extract would participate in the effect.

In previous reports, the effects of plant-derived materials on NO production in mammalian cells or tissues were investigated. For example, the Kampo prescription Saiboku-to, containing perilla, stimulates $\mathrm{NO}$ production in cultured canine airway epithelial cells, ${ }^{20)}$ and a polyphenol fraction of red wine induces NO production in isolated rat thoracic aorta. ${ }^{37)}$ The authors are currently separating the active constituents of perilla extract and have identified certain phenolic compounds. Such results will be reported at a later date.

In conclusion, Perilla frutescens, a common Japanese garnishing vegetable that is also used as an herbal medicine, induces NO production in cultured murine mesangial cells. The results of the present study coupled with the authors' previous work, which demonstrated that perilla extract inhibits cytokine-induced proliferation of cultured murine mesangial cells, suggest that $P$. frutescens represents a promising agent for the prevention of glomerulonephritis.

\section{REFERENCES}

1) Honda G., Koezuka Y., Kamisako W., Tabata M., Chem. Pharm. Bull., 34, 1672-1677 (1986).

2) Koezuka Y., Honda G., Tabata M., Planta Med., 47, 480-482 (1985).

3) Kurita N., Koike S., Agric, Biol. Chem., 46, 159-166 (1982).

4) Imaoka K., Inouye S., Jpn. J. Allergol., 42, 74-80 (1993).

5) Tanaka H., Abe T., Inagaki N., Nagai H., J. Traditional Med., 12, $400-401$ (1995).

6) Ueda H., Yamazaki M., J. Traditional Med., 12, 392-393 (1995).

7) Ueda H., Yamazaki M., Biosci. Biotech. Biochem., 61, 1292-1295 (1997).

8) Borchers A. T., Hackman R. M., Keen C. L., Stern J. S., Gershwin M. E., Am. J. Clin. Nutr., 66, 1303-1312 (1997).

9) Ono T., Yashiro M., Muso E., Honda G., Yoshida H., Sasayama S., Nephrology, 4, 367-372 (1998).

10) Makino T., Ono T., Muso E., Honda G., Planta Med., 64, 541-545 (1998).
11) Raij L., Baylis C., Kidney Int., 48, 20-32 (1995).

12) Kone B. C., Baylis C., Am. J. Physiol., 41, F561-F578 (1997).

13) Lahera V., Salom M. G., Miranda-Guardiola F., Moncada S., Romero J. C., Am. J. Physiol., 261, F1033--F1037 (1991).

14) Baylis C., Harvey J., Engels K., J. Am. Soc. Nephrol., 5, 211-214 (1994).

15) Zou A. P., Wu F., Cowley A. W., Hypertension, 31, 271-276 (1998).

16) Shultz P. J., Raij L., J. Clin. Invest., 90, 1718-1725 (1992).

17) Garg U., Hassid A., Am. J. Physiol., 257, F60-F66 (1989).

18) Studer R. K., Derubertis F. R., Craven P. A., J. Am. Soc. Nephrol., 7, 999-1005 (1996).

19) Craven P. A., Studer R. K., Felder J., Phillips S., DeRubertis F. R., Diabetes, 46, 671-681 (1997).

20) Tamaoki J., Kondo M., Chiyotani A., Takemura H., Konno K., Jap. J Pharmacol., 69, 29-35 (1995).

21) MacKay K., Striker L. J., Elliot S., Pinkert C. A., Brinster R. L., Striker G. E., Kidney Int., 33, $677-684$ (1988)

22) Rockett K. A., Awburn M. M., Cowden W. B., Clark I. A., Infect. Immun., 59, 3280-3283 (1991)

23) Chomczynski P., Sacchi N., Anal, Biochem., 162, 156-159 (1987).

24) Mosmann T., J. Immunol. Methods, 65, 55-63 (1983).

25) Terada Y., Yamada T., Nakashima O., Tamamori M., Ito H., Sasaki S. Marumo F., J. Am. Soc. Nephrol., 8, 51-60 (1997).

26) Kunz D., Mühl H., Walker G., Pfeilschifter J., Proc. Natl. Acad. Sci. U.S.A., 91, 5387-5391 (1994).

27) Cattell V., Cook T., Moncada S., Kidney Int., 38, 1056-1060 (1990).

28) Cook H. T., Sullivan R., Am. J. Pathol., 139, 1047-1052 (1991).

29) Cook H. T., Ebrahim H., Jansen A. S., Foster G. R., Largen P., Cattel V., Clin. Exp. Immunol., 97, 315-320 (1994).

30) Bremer V., Tojo A., Kimura K., Hirata Y., Goto A., Nagamatsu T., Suzuki Y., Omata M., J. Am. Soc. Nephrol., 8, 1712-1721 (1997).

31) Bulliar T. R., Curran R. D., Harbrecht B. G., Stuehr D. J., Demetris A J., Simmons R. L., J. Leuk. Biol., 48, 565-569 (1990).

32) Gabbai F. B., Boggiano C., Peter T., Khang S., Archer C., Gold D. P., Kelly C. J., J. Immunol., 159, 6266-6275 (1997).

33) Aiello S., Noris M., Remuzzi G., Mineral Electrol. Metab., 23, 151 156 (1997).

34) Furusu A., Miyazaki M., Abe K., Tsukasaki S., Shioshita K., Sasaki O., Miyazaki K., Ozono Y., Koji T., Harada T., Sakai H., Kohno S., Kidney Int., 53, 1760-1768 (1998).

35) Tada M., Matsumoto R., Yamaguchi H., Chiba K., Biosci. Biotech. Biochem., 60, 1093-1095 (1996).

36) Nikolovskacoleska Z., Suturkova L., Dorevski K., Krbavcic A., Solmajer T., Quant. Struct.-Act. Rel., 17, 7-13 (1998).

37) Andriambeloson E., Kleschyov A. L., Muller B., Beretz A., Stoclet J. C., Andriantsitohaina R., Brit. J. Pharmacol., 120, 1053-1058 (1997). 